\title{
NILAI KEARIFAN LOKAL SUNDA SEBAGAI BASIS TATA KELOLA PEMERINTAHAN YANG BAIK (GOOD GOVERNANCE)
}

\author{
Oleh \\ Lusiana Rahmatiani
}

\author{
ABSTRACT \\ LOCAL WISDOM SUNDA VALUE BASIS AS GOOD GOVERNANCE \\ ( GOOD GOVERNANCE )
}

Implementation of development in the era of regional autonomy not reflect the potential and social conditions of society. Therefore, we have developed a model of development that adopt the values of local wisdom (especially local wisdom Sunda) so that the program is implemented in line with the cultural values of the growing community. This research was conducted using qualitative approach with case study method. The subject of research is composed of two elements, including government and society. The results showed; (1) The challenge faced in putting the value of local knowledge as a basis Sundanese good governance (good governance) amid the onslaught of globalization, which in principle every program run will face problems, both issues that are trivial or complex. Also of the assumption that the policy is applied based on local wisdom is regionalism, old-fashioned, traditional, and is regarded as a setback for democracy as if back in the past in the modern era already.

\section{Keywords : Good Governance and Local Wisdom Sunda Values}

\begin{abstract}
ABSTRAK
Pelaksanaan pembangunan di era otonomi daerah belum mencerminkan potensi dan kondisi sosial masyarakat. Karena itu, perlu dikembangkannya suatu model pembangunan yang mengadopsi nilai-nilai kearifan lokal (khususnya kearifan lokal sunda) sehingga program yang dilaksanakan sejalan dengan nilai-nilai kultural yang berkembang dimasyarakat. Penelitian ini dilakukan menggunakan pendekatan kualitatif dengan metode studi kasus. Subjek penelitian terdiri dari dua elemen, meliputi pemerintah dan masyarakat. Hasil penelitian menunjukan; (1) Tantangan yang dihadapi dalam menempatkan nilai kearifan lokal sunda sebagai basis tata kelola pemerintahan yang baik (good governance) ditengah terpaan arus globalisasi, dimana pada prinsipnya setiap program yang dijalankan akan menghadapi masalah, baik masalah yang sifatnya sepele maupun yang kompleks. Juga banyaknya anggapan bahwa kebijakan berbasis kearifan lokal yang diterapkan bersifat kedaerahan, kuno, tradisional, dan dianggap sebagai suatu kemunduran demokrasi karena seakan kembali pada masa lalu di era yang sudah modern.
\end{abstract}

Kata Kunci : Tata Kelola Pemerintahan yang Baik dan Nilai Kearifan Lokal Sunda 


\section{Pendahuluan}

Mengenai penelitian tata kelola pemerintahan yang baik (good goernance) penting dilakukan karena sejumlah alasan. Munculnya ketidakpercayaan terhadap pemerintah yang menjadikan rendahnya tingkat partisipasi masyarakat dalam mendukung pembangunan berkelanjutan, juga adanya citra buruk pemerintahan dikalangan masyarakat yang mengakibatkan maraknya tindakan korupsi, kolusi dan nepotisme dikalangan pejabat pemerintah.

Pelaksanaan konsep good governance dalam pembangunan bangsa. Mardiasmo (dalam Tangkilisan, 2005, hlm. 114) menjelaskan bahwa orientasi pembangunan sektor publik adalah untuk menciptakan kepemerintahan yang baik (good governance). Kondisi ini berupaya untuk menciptakan suatu penyelenggaraan manajemen pembangunan yang solid dan bertanggungjawab sejalan prinsip demokrasi, efisien, pencegahan korupsi, baik secara politik maupun administratif.

Penerapan kebijakan otonomi daerah sebagai salah satu bentuk inisiatif yang dilandasi keinginan kuat mempercepat proses pembangunan nasional dalam prakteknya tidak secara spontan dapat memenuhi sisi ideal yang diharapkan, hal tersebut amat bergantung pada keberhasilan setiap elemen daerah dalam menjalankan konsepsi sebagaimana yang dicanangkan. Untuk mendukung ketercapaian pembangunan di era otonomi daerah diperlukan partisipasi aktif masyarakat dalam mendukung program pembangunan. Dijelaskan Sedarmayanti (2012, hlm. 3) bahwa pemerintahan yang baik hanya dapat tercipta apabila dua kekuatan saling mendukung, yakni warga yang bertanggungjawab, aktif dan memiliki kesadaran bersama dengan pemerintah yang terbuka, tanggap, mau mendengar, dan mau melibatkan. Sebagaimana Bastian (2006, hlm. 338) yang menjelaskan bahwa tujuan program otonomi daerah adalah menciptakan kehidupan politik yang lebih demokratis, menciptakan sistem yang lebih menjamin pemerataan dan keadilan, memungkinkan setiap daerah menggali potensi natural dan kultural yang dimiliki, dan kesiapan menghadapi tantangan globalisasi.

Partisipasi masyarakat dalam setiap proses pembuatan kebijakan merupakan hal penting sebagai cermin perjalanan demokrasi di suatu negara. Hal ini menjadi sangat tepat ketika partisipasi publik kemudian diangkat menjadi salah satu prinsip yang harus dijalankan oleh pemerintah dalam upaya mewujudkan tata kelola pemerintahan yang baik (good governance). Pentingnya partisipasi publik pada gilirannya memperoleh momentum yang tepat seiring berkembangnya otonomi daerah di Indonesia yang memberikan keleluasaan yang lebih besar bagi daerah untuk merancang dan menentukan sendiri jenis pelayanan yang paling dibutuhkan dan merefresentasikan harapan masyarakat. Hal tersebut dapat diasumsikan bahwa kepemerintahan yang baik tidak dapat tercapai tanpa didukung oleh keberadaan masyarakat yang kuat sebagai modal sosial paling utama.

Akan tetapi, harapan-harapan sebagaimana diungkap di atas sampai saat ini masih menemui berbagai kendala. Pertama, otonomi daerah berdampak pada munculnya "raja-raja kecil" yang seakan menguasai daerah yang dipimpinnya. Kedua, pemahaman Pemerintah Daerah mengenai konsepsi otonomi daerah masih kurang. Ketiga, adanya tindakan sewenangwenang dari Pemerintah Daerah dalam menjalankan roda pemerintahan di daerah. Hal tersebut didasarkan pada hasil pengamatan dan telaah terhadap beberapa informasi yang diperoleh dari media massa.

Adanya desakan dan pengaruh budaya asing dalam iklim globalisasi menjadikan pentingnya menjaga dan memperkuat kearifan lokal yang sarat nilai dalam segala aspek kehidupan, termasuk dalam bidang pemerintahan dan pembangunan. Kearifan lokal yang menjadi basis pembangunan di Kabupaten Purwakarta berangkat dari budaya Sunda sebagai karakteristik masyarakat Jawa Barat yang sarat akan nilai. Dikatakan demikian karena berdasarkan pandangan yang dijelaskan Rosidi (2010, hlm. 50) bahwa: pandangan hidup orang Sunda menganjurkan agar rukun, mendahulukan kebersamaan (karageman), mempunyai 
pertimbangan yang adil, mempunyai pandangan kedepan sehingga selalu siap kalau pada suatu waktu menghadapi kesukaran, harus menyesuaikan diri dengan lingkungan yang baru, harus bijaksana sehingga dapat mencapai hasil tanpa menimbulkan ketegangan atau kekeruhan, suka tolong-menolong, hemat serta pandai mengatur rizki, tahu diri, tahu aturan, kalau berkata tidak sembarangan sehingga tak mudah berubah-ubah, sabar dan tekum dalam mengerjakan sesuatu dan lain-lain.

kearifan lokal budaya Sunda sebagai basis pembangunan daerah amat relevan dengan upaya pencapaian suatu tata kelola penerintahan yang baik (good governance) karena tidak satupun nilai yang terkandung di dalamnya bertentangan dengan nilai-nilai etika dan keutamaan. Selain itu, kearifan lokal dapat pula dimanfaatkan sebagai pendekatan dalam menghadapi berbagai konflik yang terjadi dalam masyarakat karena kita sadari betul bahwa kondisi sosial kultural masyarakat yang beragam amat potensial terjadinya konflik.

Urgensi pentingnya dikembangkan pembangunan yang berorientasi pada manusia dijelaskan Rosidi (2010, hlm. 24) bahwa pembangunan daerah harus mengutamakan pembangunan manusia. Lebih lanjut, ia menjelaskan bahwa sosok manusia Sunda yang diperlukan dalam pembangunan ialah manusia kreatif yang berani mengemukakan keyakinan dan menuntut haknya di pihak rakyat dan manusia yang menganggap jabatan yang dipercayakan kepadanya bukan sebagai alat untuk memperlihatkan kekuasaan secara sewenang-wenang, melainkan sebagai amanat yang harus dlaksanakan penuh pengabdian pada masyarakat di pihak elit politik dan elit pelaksana administratif.

Mengacu pada pemikiran diatas, maka penulis tertarik untuk mengkaji dan menganalisis lebih dalam ikhwal tata kelola pemerintahan yang menempatkan nilai kearifan lokal sunda sebagai basis pembangunannya. Karena itu, penulis mengangkat hal tersebut ke dalam suatu studi penelitian dengan judul "Nilai Kearifan Lokal Sunda sebagai Basis Tata Kelola Pemerintahan yang Baik (Good Governance)". Penelitian ini difokuskan pada tantangan yang dihadapi dalam menempatkan nilai kearifan lokal sunda sebagai basis tata kelola pemerintahan yang baik (good governance) ditengah terpaan arus globalisasi

\section{Metode}

Metode penelitian ini menggunakan pendekatan kualitatif dengan metode studi kasus. Subjek dalam penelitian terdiri dari dua unsur, meliputi unsur pemerintah dan masyarakat yang kesemuanya diseleksi berdasarkan kompetensi, tugas, pokok dan fungsi yang diembannya serta dianggap dapat memberikan sejumlah informasi terkait dengan penelitian mengenai penguatan nilai kearifan lokal sebagai basis tata kelola pemerintahan yang baik (good governance). Lokasi penelitian terletak di Kantor Pemerintahan Daerah serta wilayah administratif Kabupaten Purwakarta. Teknik pengumpulan data dilakukan melalui wawancara, observasi, studi dokumentasi. Setelah data terkumpul, kemudian data dianalisis menggunakan analisis data kualitatif mengacu pada tiga alur kegiatan yang terjadi secara bersamaan yaitu reduksi data, penyajian data, dan penarikan kesimpulan/ verifikasi (Miles dan Huberman, 2007, hlm. 16-18). 


\section{Pembahasan}

Berdasarkan data hasil temuan di lapangan yang diperoleh melalui wawancara, observasi dan studi dokumentasi, pada bagian ini akan dikemukakan hasil analisis terhadap temuan penelitian terkait penguatan nilai kearifan lokal sunda sebagai basis tata kelola pemerintahan yang baik.

\section{Tantangan yang dihadapi dalam menempatkan nilai kearifan lokal sunda sebagai basis tata kelola pemerintahan yang baik (good governance) ditengah terpaan arus globalisasi}

Sebagaimana dipahami bersama bahwa pada prinsipnya setiap program yang dijalankan akan menghadapi masalah, baik masalah yang sifatnya sepele maupun yang kompleks. Hal ini pula yang terjadi dalam pelaksanaan pembangunan di Kabupaten Purwakarta, dimana berdasarkan hasil penelitian yang dilakukan ditemui sejumlah tantangan yang mendera berjalannya program. Tantangan ini biasanya bermula dari adanya perbedaan berpikir antar elemen (pemerintah maupun masyarakat) terhadap orientasi pembangunan.

Banyaknya anggapan bahwa kebijakan berbasis kearifan lokal yang diterapkan bersifat kedaerahan, kuno, tradisional, dan dianggap sebagai suatu kemunduran demokrasi karena seakan kembali pada masa lalu di era yang sudah modern. Ditambah dengan adanya perilaku anarkis yang dimunculkan oleh masyarakat sebagai bentuk protes akan kebijakan pemerintah, seperti nampak pada insiden perusakan sejumlah patung di Kabupaten Purwakarta. Hal ini menandakan bahwa masih ada ketimpangan orientasi pembangunan yang dimaksud pemerintah dengan anggapan masyarakat akan orientasi yang bersangkutan itu.

Terjadinya tindakan anarkis dari sebagian masyarakat merupakan luapan emosional masyarakat yang merasa bahwa pembangunan yang dilakukan tidak senada dengan harapan yang diinginkan masyarakat. Hal tersebut boleh jadi karena ketidaksesuaian program pembangunan dengan kultur masyarakat yang sebagaimana kita ketahui bahwa masyarakat Purwakarta yang mayoritas muslim amat menjunjung tinggi nilai-nilai agama dan menempatkannya sebagai aspek utama dan pedoman hidup. Kuatnya keyakinan masyarakat terhadap agamanya itu, menjadikan masyarakat menolak segala bentuk tindakan yang dianggap menyimpang dari ajaran agama. Dalam konteks ini, pendirian patung dipahami sebagai tindakan yang tidak sesuai dengan nilai-nilai yang diajarkan dalam agama islam, terlebih patung yang didirikan dianggap sebagai tokoh yang menyimbolkan agama yang selain Islam.

Bagi pihak yang kontra, pembangunan patung-patung amat sedikit membawa kebermanfaatan dibandingkan kemadharatannya. Dari sisi biaya, pembangunan ini diangap suatu pemborosan yang sebenarnya dapat dialokasikan untuk meningkatkan kesejahteraan masyarakat. Jikapun pembangunan itu disesuaikan dengan karakteristik masyarakat lokal, maka ada satu unsur yang terlewatkan oleh pemerintah,yakni karakteristik masyarakat religius (muslim) yang ada pada masyarakat Purwakarta. Pembangunan daerah harus melihat kondisi, situasi dan karakteristik masyarakatnya. Purwakarta sebagian besar adalah umat muslim yang menganggap bahwa keberadaan patung merupakan bagian dari tindakan syirik.

Tatangan lain yang muncul adalah belum efektifnya kerjasama yang dijalin antara pemerintah, masyarakat, dan sektor swasta. Dalam hal ini, khususnya sektor swasta hanya terkesan hanya formalitas semata dalam melaksankaan pemberdayaan masyarakat, dalam arti belum menganggap bahwa pemberayaan merupakan bagian dari tanggungjawabnya sebagai warganegara. Tantangan yang muncul tersebut tidak terlepas dari adanya kecerobohon-kecerobohan pemimpin daerah, dalam arti peluang terjadinya "kolusi dan 
nepotisme" masih besar peluang untuk terjadi. Oleh karena itu, perlu ada penegakkan supremasi hukum yang berlaku bagi semua.

Munculnya tantangan dalam pembangunan, baik dalam pembangunan di bidang sosial budaya, bidang ekonomi, bidang fisik dan sarana, serta bidang pemberdayaan masyarakat semuanya bertitik pangkal dari belum adanya komitmen bersama untuk maju dan berkembang serta membangun daerah. Hal ini dinilai sebagai faktor utama sehingga permasalahan-permasalahan masih saja muncul dalam pembangunan daerah. Selain itu, pemaknaan akan hakikat nilai kearifan lokal sebagai basis pemerintahan yang baik nampaknya belum dipahami secara menyeluruh oleh seluruh lapisan, baik pegawai pemerintah, masyarakat, swasta dan lain sebagainya yang cenderung masih menempati posisi sebagai slogan belaka.

Melihat gambaran tersebut, maka pembangunan berorientasi nilai kearifan lokal dalam prakteknya belum mencerminkan kesesuaian antara program dengan karakteristik masyarakat. Padahal salah satu prinsip yang harus dipenuhi dalam pembangunan di era otonomi daerah adalah pembangunan harus sesuai dengan kondisi sosial kultural masyarakatnya. Perlu dipahami bahwa pembangunan berbasis kearifan lokal bukan hanya terletak pada infrastruktur yang dihiasi oleh patung-patung dan para pegawai pemerintah yang berpakaian hitam putih, akan tetapi justru perilaku masyarakat lah yang seharusnya dibentuk agar sesuai dengan karakter orang Sunda yang ramah, tidak arogan, jujur, hemat dan bersahaja.

Sebagaimana Malau (2013) yang menjelaskan bahwa masyarakat selain sebagai obyek yang diatur dan diperintah juga sebagai pengguna pelayanan serta sebagai subyek atau pelaku penyelenggaraan pemerintahan daerah atas partisipasinya. Karena itu, good governance memerlukan interaksi seimbang antara pemerintah, masyarakat dan swasta yang dapat diwujudkan melalui kerjasama dan koordinasi, mengutamakan dialog, negosiasi menuju musyawarah pada masyarakat demi tercapainya partisipasi, transparansi, responsivitas, orientasi pada konsensus, kesetaraan, efektifitas, dan akuntabilitas pada penyelenggaraan pemerintahan.

Nilai kearifan lokal yang ada bukan hanya diketahui dan dipahami semata, tetapi yang terpenting adalah nilai-nilai tersebut mampu dilaksanakan dalam kehidupan seharihari, karena nilai-nilai budaya yang berusaha dipertahankan masyarakat pada akhirnya akan menjadi sebuah tradisi sekaligus merupakan identitas bagi masyarakat yang bersangkutan. Sebagaimana Rosidi (2011) yang menjelaskan bahwa kearifan lokal merujuk pada pengertian kemampuan kebudayaan setempat dalam menghadapi pengaruh kebudayaan asing pada waktu kedua kebudayaan itu berhubungan.

Kearifan lokal merupakan kekayaan intelektual karena merupakan buah pemikiran leluhur bangsa yang harus dilestarikan. Sekalipun demikian, nilai kearifan lokal ini harus menyeimbangkan dengan kemajuan jaman, termasuk dalam pembangunan daerah, jangan sampai kita mempertahankan tradisi lantas menutup diri dari kemajuan ilmu pengetahuan dan teknologi. Akan tetapi, sudah barang tentu nilai lokal harus hidup dan berkembang selaras dengan nilai-nilai modern, sekalipun dalam kenyataannya nilai-nilai budaya luhur kita (khususnya Sunda) mulai meredup, memudar, dan kehilangan maknanya.

Terdapat sejumlah aspek yang dijalankan dalam melaksanakan pembangunan berbasis kearifan lokal, yakni adanya prinsip keterbukaan dan transparansi antar pemerintah dan masyarakat, mengimplementasikan prinsip silih asah, silih asuh, silih asih, serta mengkolaborasikan antara kekuatan pikiran, badan, dan batin sebagaimana tercermin dalam pepatah Sunda "cing caringcing pageuh kancing" dan "set saringset pageuh iket" yang menegaskan bahwa pembangunan harus mampu menyelaraskan kekuatan hati, sifat kasih sayang, dan kekuatan pikiran yang berjalan selaras dan seimbang, dalam arti mampu berpikir untuk maju tanpa mengesampingkan nilai-nilai kasih sayang antarsesama. 
Silih asah berorientasi pada peningkatan kualitas cara berpikir, mengasah kemampuan untuk mempertajam pikiran dengan ilmu dan pengalaman. Seperti tercermin dalam ungkapan sunda "peso mintul mun terus diasah tangtu bakal seukeut" artinya pisau tumpul kalau terus diasah akan tajam juga. Silih asih mengandung makna bahwa setiap individu harus memiliki empati, rasa belas kasih, tenggang rasa, simpati terhadap kehidupan sekelilingnya atau memiliki rasa sosial yang tinggi. Seperti tercermin dalam ungkapan sunda "ka cai kudu saleuwi ka darat kudu selebak" arti utamanya adalah kebersamaan. "Ulah pagiri-giri calik, ulah pagirang-girang tampian" artinya jangan ada permusuhan di antara manusia. Selanjutnya silih asuh mengandung makna bahwa kasih sayang harus diwujudkan dalam tindakan nyata. Harus hormat kepada yang lebih tua, kepada sesama harus saling menjaga, kepada yang lebih muda harus mampu mengayomi dan memberi contoh yang baik.

Selain itu memiliki filosofi silih asah, silih asih, dan silih asuh, orang Sunda juga memiliki paribasa hade goreng ku basa artinya baik buruknya itu ada ucapannya (Rosidi, 2010). Hal ini merujuk pada perlunya jalinan komunikasi yang baik antara pemerintah dan masyarakat dalam menyusun dan melaksanakan program pembangunan, sehingga kebijakan pemerintah itu dapat selaras dengan keinginan dan harapan masyarakat.

Berdasarkan hasil observasi yang dilakukan terhadap sejumlah bangunan yang ada di Kabupaten Purwakarta, semakin memperkuat bahwa tata kelola pemerintahan berbasis pada nilai kearifan lokal yahng terutama nampak dari motif bangunan yang bernuansa nyentrik, estetik, dan "nyunda". Berikut beberapa potret bangunan yang penulis dapatkan dari hasil observasi.

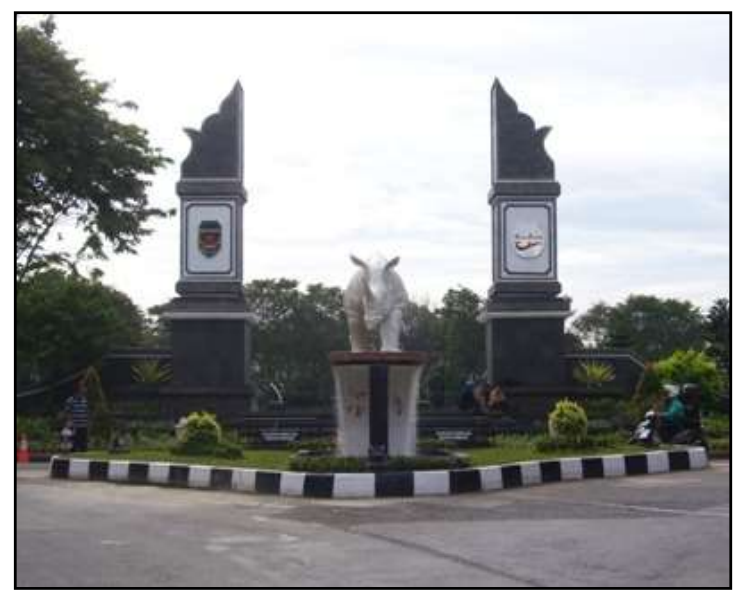

Melihat gambar di atas, pada dasarnya bangunan-bangunan yang ada di Kabupaten Purwakarta mencerminkan masa lalu daerah dan potensi yang dimiliki oleh daerah tersebut. Patung badak yang ada di daerah Situ Buleud merupakan simbol yang menceritakan bahwa konon di daerah tersebut pada masa lalu merupakan tempat pemandian badak atau dalam bahasa Sunda dikenal "pangguyangan badak", karena itu di daearah tersebut dibangunlah patung badak. Selanjutnya terdapat contoh lain yang menunjukkan jatidiri dan potensi yang ada di Kabupaten Purwakarta. 


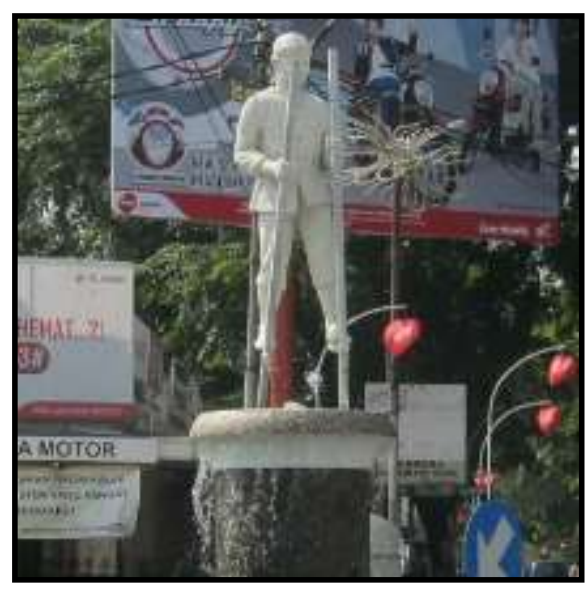

Patung "egrang" mengingatkan masyarakat Purwakarta pada permainan tradisional yang sudah mulai dilupakan oleh anak-anak masa kini. Saat ini anak-anak lebih banyak menonoton $\mathrm{tv}$, bermain game online, menggunakan handphone, dan lain sebagainya yang mendukung terciptanya masyarakat yang individualistik. Parahnya, dengan menonton tayangan-tayangan yang tersedia di televisi, internet dan media lainnya tanpa bimbingan dari orang tua dapat berakibat munculnya perilaku negatif anak, seperti, perkelahian antarpelajar, pemerkosaan, dan tindakan-tindakan lainnya yang tidak mencerminkan karakter orang Sunda.

Pembangunan daerah yang menganggap dirinya berbasis kearifan lokal adalah tidak semuanya benar jika pelestarian nilai tersebut hanya nampak sekedar pernyataan simbolik, tanpa dibarengi dengan penghayatan dan pengamalan dalam kehidupan seharihari. Seharusnya kearifan lokal berfungsi sebagai filter ketika terjadi benturan antara budaya lokal dengan tuntutan perubahan dan hendaknya menjadi pedoman dalam bersikap dan berperilaku.

Pelaksanaan pembangunan pada dasarnya tidak dapat terwujud tanpa adanya kerjasama antara pemerintah dan pihak-pihak lainnya baik masyarakat ataupun dengan pihak swasta. Oleh karena itu, pemerintah Kabupaten Purwakarta mewajibkan kepada para pengusaha yang ada di Kabupaten Purwakarta untuk berkontribusi secara nyata melalui partisipasi aktif terhadap pembangunan daerah. Disamping itu, pemerintah juga terus mendorong agar masyarakat mau dan dengan sukarela mendukung keberlaksanaan pembangunan di Kabupaten Purwakarta.

Pola pembangunan yang berbasis nilai lokal ini dipandang oleh Bastian (2006) sebagai tujuan program pembangunan di era otonomi daerah, dimana pemerintah daerah harus mampu menciptakan kehidupan politik yang lebih demokratis, menciptakan sistem yang lebih menjamin pemerataan dan keadilan yang memungkinkan setiap daerah menggali potensi natural dan kultural yang dimiliki dalam menghadapi tantangan globalisasi.

Urgensi penguatan nilai kearifan lokal sunda dalam menghadapi tantangan pembangunan daerah, dijelaskan Mulyadi (2012) yang mengemukakan bahwa kearifan lokal dapat melahirkan semangat pembangunan, kesejahteraan masyarakat, serta menciptakan keadilan ekonomi. Tegasnya, kearifan lokal jika didayagunakan dengan tepat dengan dukungan ilmu dan teknologi, diyakini akan mampu mendorong masyarakat ke arah kemajuan yang dicita-citakan oleh setiap bangsa, yakni menjadi masyarakat madani, masyarakat sipil, masyarakat yang berkeadaban, masyarakat yang mulia. Tradisi budaya lokal khususnya tradisi Sunda mempunyai pesan agar setiap manusia dapat menjadi manusia sejati, yakni manusia yang memiliki ciri yakni dapat bermanfaat bagi kehidupan semua orang. 
Kaitannya dengan penciptaan good governance, maka hal utama yang harus diperbaiki adalah mutu dan kualitas pelayanan publik, dimana sistem pelayanan harus mampu disesuaikan dengan kebutuhan, tuntutan dan karakteristik masyarakat. Terabaikannya nilai-nilai etika dan budaya kerja dalam birokrasi dapat melemahkan disiplin kerja, etos kerja, dan produktivitas kerja. Terkait dengan hal tersebut, yang harus dilakukan dalam menyongsong tata kelola pemerintahan yang baik adalah pemerintah bersama dengan masyarakat harus mampu menjalankan prinsip-prinsip dalam good governance meliputi; partisipasi (participation), kepastian hukum (rule of low), transparansi (transparency), tanggung jawab (responsiveness), berorientasi pada kesepakatan (consensus orientation), keadilan (equity), efektivitas dan efisiensi (effectiveness and efficiency), akuntabilitas (accountability), visi strategik (strategic vision) (UNDP dalam Sedarmayanti, 2013)

\section{Referensi}

Bastian, I, (2006). Manual Akuntansi Keuangan Pemerintahan Daerah. Yogyakarta : BPFE.

Malau, H. (2013). Implementasi Good Governance Pada Pemerintahan Nagari di Sumatera Barat. Jurnal. Jurnal Tingkap Vol. IX No. 2 Th. 2013. Padang: Universitas Negeri Padang

Miles, M \& Huberman, A. M. (2007). Analisis Data Kualitatif. Jakarta: UI-Press.

Mulyadi, D. (2012). Pembangunan Berkarakter : Sebuah Pilihan Untuk Indonesia. Purwakarta : Badan Perencanaan dan Pembangunan Daerah kabupaten Purwakarta.

Rosidi, A. (2010). Mencari Sosok Manusia Sunda. Jakarta: PT Dunia Pustaka Jaya.

Rosidi, A. (2011). Kearifan Lokal (dalam Prespektif Budaya Sunda). Bandung: PT Kiblat Buku Utama.

Sedarmayanti, (2003). Good Governanace (Kepemerintahan Yang Baik) Dalam Rangka Otonomi Daerah : Upaya Membangun Organisasi Efektif dan Efisisen Melalui Restrukturisasi dan Pemberdayaan. Bandung : Mandar Maju.

Tangkilisan, NH. (2005). Manajemen Publik. PT. Gramedia Widiasarana. Indonesia : Jakarta. 